\title{
$\delta$ aminolevulinic acid dehydratase (ALAD) gene polymorphism of marine taskforce personnel whit routine exposure of lead suspended in air
}

\author{
Rini Puspitaningrum ${ }^{1, *}$, Chris Adhiyanto ${ }^{2}$, Nurmasari Sartono ${ }^{1}$, Palgunadi Palgunadi ${ }^{3}$, Solihin Solihin ${ }^{4}$, Yasuhiro \\ Yamashiro $^{5}$, and Yukio Hattori ${ }^{5}$ \\ ${ }^{1}$ UNJ, Département of Biology, Faculty of Math and Natural Sciences, Rawamangun Muka, Jakarta, Indonesia \\ ${ }^{2}$ State Islamic University Syarif Hidayatullah Jakarta, Faculty of Medicine, Indonesia \\ ${ }^{3}$ Secretary of Research and Development of the Indonesian Navy, Indonesia \\ ${ }^{4} \mathrm{UNJ}$, Département of Post-Graduate Biology Education, Rawamangun Muka, Jakarta, Indonesia \\ ${ }^{5}$ Yamaguchi University, Faculty of Medicine and Health Sciences, Japan
}

\begin{abstract}
The pollutant lead (Pb-plumbum-black lead) is toxic. Organisms in nature cannot naturally suppres its concentration. Special Capital Region of Jakarta is a metropolitan city with densest highway traffic in the world, especially in and around the Marunda area, which is the location 24-hour non-stop loading and unloading activities of various businesses. With that environmental condition, in the Marunda area of Jakarta lies the Naval base where the Marine Taskforce Personnel are stationed. The environmental condition allows the personnel to be quite frequently exposed to lead. This research aims to detect the ALAD gen mutation in the Marine Taskforce personnel as a mapping of the level of ALAD gene mutation frequency in the Marines of the Jakarta area. The research was conducted in a period of [insert data]. The sampling applied the purposive sampling method with a sample size of 100 Marines. The research results show that there was no ALAD gene mutation in the 100 Marines. This could depict a good energy status of the 100 Marines stationed in the Marunda area. With no mutation found in the ALAD gene, that means the process of oxygen binding with hemoglobin has no disruption in energy synthesis.
\end{abstract}

\section{Preface}

The pollutant lead (Pb-plumbum-black lead) is toxic. Organisms in nature cannot naturally suppres its concentration. One of the sources of lead pollutant is the vehicle smoke coming from imperfect combustion. Special Capital Region of Jakarta is a metropolitan city with densest highway traffic in the world, especially in and around the Marunda area, which is the location 24hour non-stop loading and unloading activities of various businesses. As a capital city, Jakarta is an important economic center which needs various means of transportation. The increase of transportation causes the increase of air pollution which in turn results in the decrease of air quality. With that environmental condition, in the Marunda area of Jakarta lies the Naval base where the Marine Taskforce Personnel are stationed. The environmental condition allows the personnel to be quite frequently exposed to lead.

Puspita et al, [1] stated that from the population of Jakarta, there is a population of elementary school children with ALAD gene mutation. A research team has studied the existence of those children living and exposed to the lead particulate in the suburban area of Jakarta. This is in accordance with the further research regarding the ALAD gene mutation whose frequency is increasing to 1 in 9 people [2] Lead particles lie in the lowest air layer of approximately 1 meter. They have the risk of being inhaled by any age group members. This fact is the cause of the increase of public caution towards the increasing air pollution in Jakarta. This increase eventually heightens the risk factor of children, especially those in the age of 6-9 years (elementary school grades 1-2) with a height of $100-140 \mathrm{~cm}$, to be exposed to lead. This also affects suceptible working adults.

Thus far there is no complete data describing the condition of ALAD gene mutation among adults from various levels of society. The team started to conduct detection of ALAD gene mutation in Marine Taskforce personnel as the mapping of the level of ALAD gene mutation in the Jakarta area. The selection of Marine Taskforce personnel was based on the consideration that the Marine personnel are the main defense for community and units of defence. In this population, the energy profile of the main defense personnel would also be evaluated, especially in the Marunda area of Jakarta. The research results would have an impact on the general profile of adults in the City of Jakarta area. This research is important due to the effects of lead to the body, which can inhibit the ALAD (deltaaminolevulinate dehydratase) enzyme that would inhibit

*Corresponding author: rini_puspitaningrum@unj.ac.id 
the heme biosynthesis, decrease hemoglobin level in the blood, change behavior, allow the decrease of academic achievements, and become the cause of degenerative diseases. The usefulness of this research are the mapping of ALAD gene polymorphism in the population of children in Jakarta, determining the plants that can absorb lead, and creating countermeasures for children which are diagnosed with the ALAD gene polymorphism.

\section{Research Methodology}

The research method employed was the descriptive method, with research sample analysis was conducted in the Laboratorium of Biochemistry and Molecular Biology, Faculty of Mathematics and Natural Sciences of Universitas Negeri Jakarta (UNJ). Sampling was conducted in the Marunda area of North Jakarta. The samples are $3 \mathrm{cc}$ of blood taken from 100 Taskforce Marine personnel. The research was conducted in a period of two years from 2017-2018. 1) Measuring hemoglobin levels and Blood cells sampling was accompanied with secondary data sampling; height, weight, blood type questionaire (not shown). 2) The isolated blood genome was tested quantitatively using nano spectrophotometer and qualitatively using electrophoresis; 3) Genome with good quality and quantity were processed to the amplification stage with PCR Stage 1; 4) Amplification results were tested qualitatively using electrophoresis; 5) PCR Stage 1 amplification result would be processed to PCR Stage 2 by first conducting dilution before the PCR Stage $2 ; 6$ ) The results of PCR Stage 2 are tested qualitatively using electrophoresis $[3,4]$.

\section{Research Results}

\subsection{The blood sampling activity of Marine Taskforce Personnel}

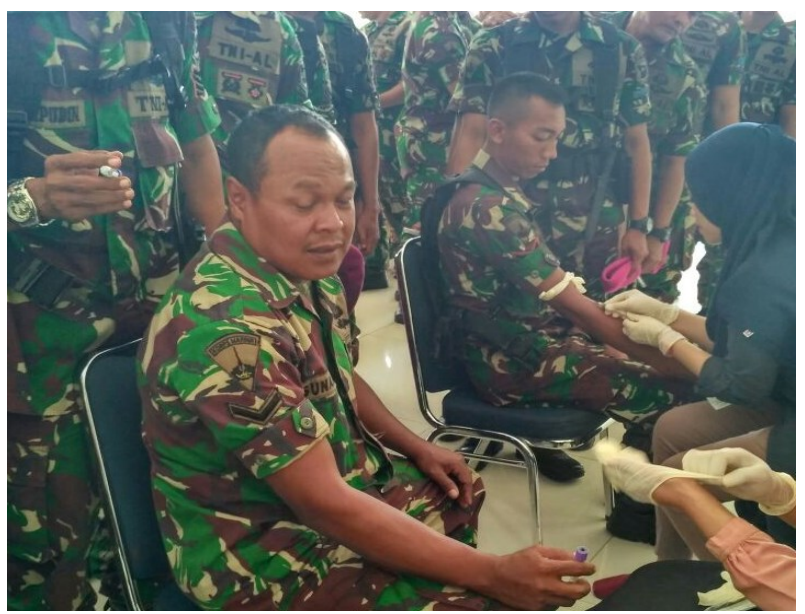

Fig. 1. The blood sampling activity.

\subsection{Results}
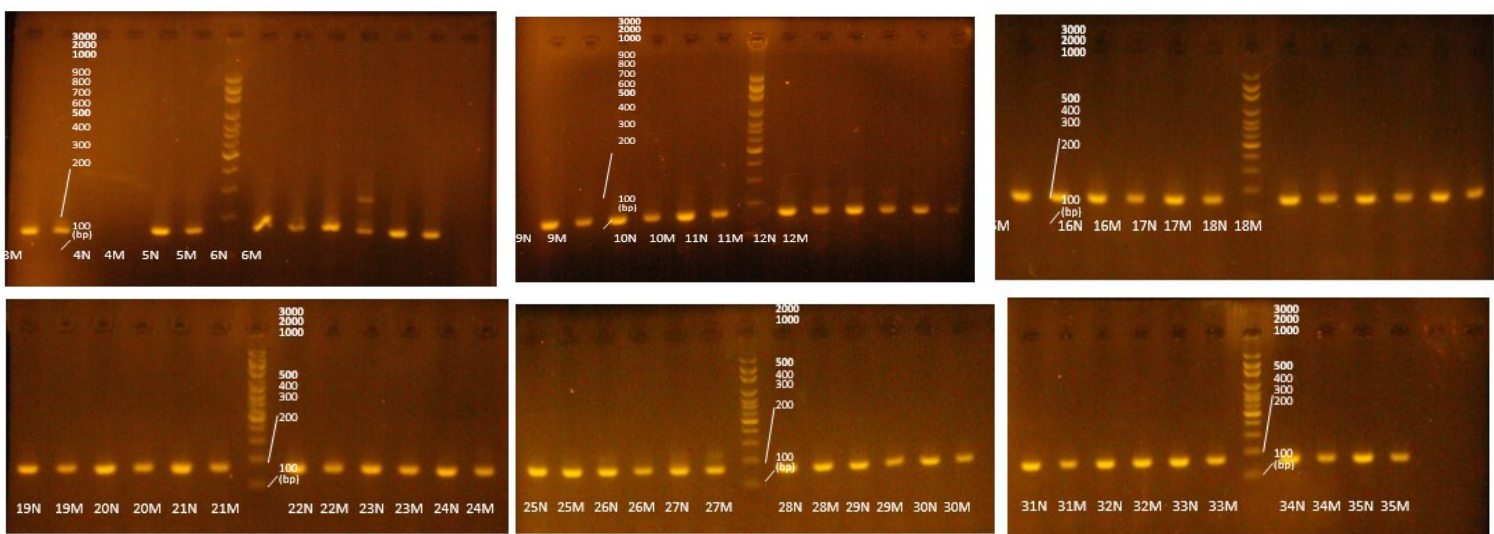
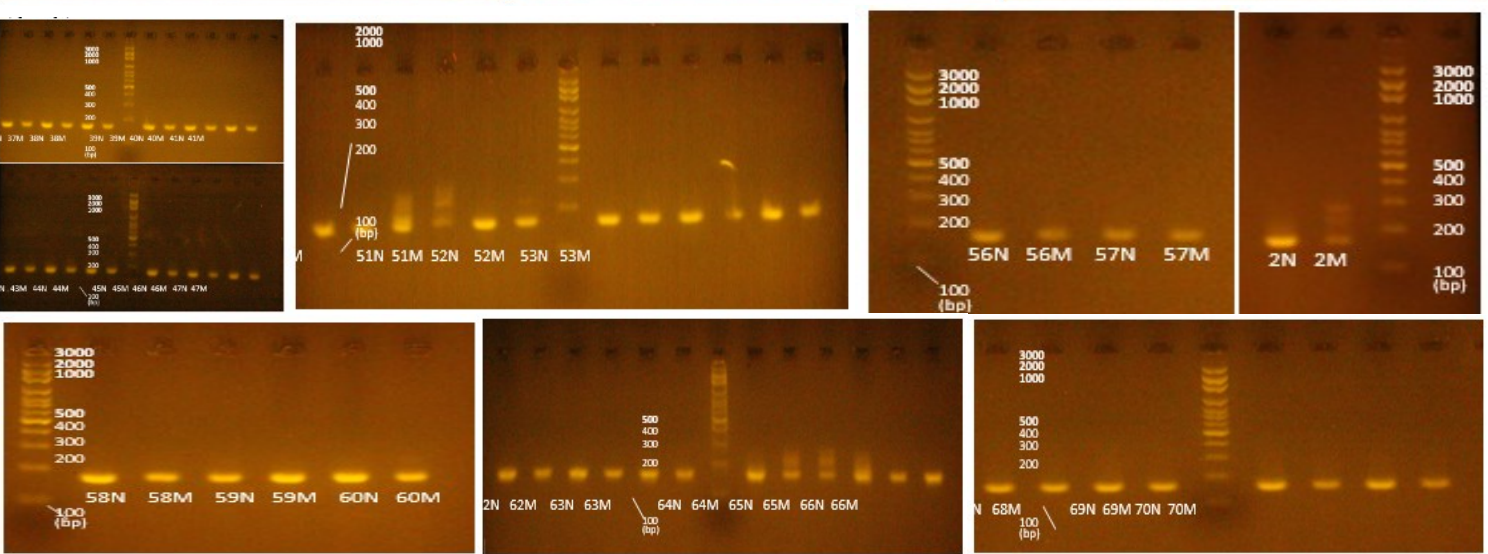

Fig. 2. elektroforesis of cells Blood. 


\subsection{Discussion}

Air pollution in the environment comes from the use of fuel containing pollutant. Motor vehicles are the main source of air pollution. Pollutant in the emission of motor vehicles can be in the form of carbon monoxide (CO), nitrogen oxide (NOx), hydrocarbon, particulate, and lead [5] Polutan which is toxic and has no natural organism capable of suppressing its levels in nature is lead. The pollutant source of lead is the emission of vehicle engines using the additives tetraethyl lead and tetramethyl lead [6] cross-reference Posman, 2000 in [3] Lead absorption in the body happens mainly through the to the digestive systems and the respiratory system [7].

According to the monitoring of the Environmental Management Impact Agency of the Special Capital Region of Jakarta 2014 the ambient air quality of Kalideres of West Jakarta has a lead concentration of $0.290 \mu \mathrm{g} / \mathrm{m}^{3}$ and the Tebet area of South Jakarta Selatan has an average lead concentration of $0.222 \mu \mathrm{g} / \mathrm{m}^{3}$. Both areas have highest concentration of lead in the air from the nine monitoring points in the Special Capital Region of Jakarta. The range of lead concentration in 2013 was $0.030-0.085 \mu \mathrm{g} / \mathrm{m}^{3}$. Data shows an increase in 2014 with the range of lead concentration of $0.010-1.390 \mu \mathrm{g} / \mathrm{m}^{3}$. The Kalideres area has an industrial and warehouse center along Jalan Daan Mogot. Kalideres is considered strategic because of the major road of Daan Mogot which is a route to the International Airport of SoekarnoHatta or the Tanjung Priok port. This results in the increase of traffic density and that together along with the increase of vehicular volume create traffic jams. For the Tebet area of South Jakarta, futher research is needed to discover the cause of the high lead concentration in the air.

The impact of lead exposure is the decrease of hemoglobin level. Based on the research of Pramudyastuti [8] lead concentration in the air has an inverse relationship with the hemoglobin level. Hemoglobin has the ability to bind oxygen. Body tissue experiencing a lack of oxygen would experience hypoxia. According to in Izah [9] prolonged hypoxia would cause fatigue, apathy, decrease of concentration, and decrease of work capacity. in Azhari [10], the symptoms of anemia have similarities with hypoxia, namely frailness, fatigue, tiredness, decrease of concentration, absent-mindedness, decrease of appetite, pale face, and low body endurance. Moreover, the increase of lead concentration in blood over $20 \mu \mathrm{g} / \mathrm{dl}$ can cause a decrease in IQ of 2-5 points [3].

The exposure of lead can also inhibit the ALAD (delta-aminolevulinate dehydratase) enzyme, due to the exposure of lead inhibiting heme biosynthesis [11] that it can cause anemia and shorten the lifetime of erythrocytes [12] The ALAD enzyme is a polymorphic enzyme because the transversion from $G$ to $C$ in the nucleotide position 177 in the coding area which produce the amino acid substitution of lysine to asparagine ALAD enzyme binds eight $\mathrm{Zn}$ atoms which function as catalyst and stabilization of the enzyme's tertiary structure. ALAD enzyme cannot bind the cofactor $\mathrm{Zn}$ due to the competition of the amount of lead in the environment inhibiting the function of ALAD enzyme. The inhibition of ALAD enzyme activity happens when the lead concentration is over $10 \mathrm{~g} / \mathrm{dL}$ in the blood.

Gene polymorphism caused by environmental toxins is the ALAD gene polymorphism [13] One of the polymorphism happening to the ALAD gene produces two alleles, namely ALAD-1 and ALAD-2. in Kelada et al. [12] was the first to differentiate the ALAD genotype in workers exposed to lead, namely the heterozygote genotype ALAD 1-2 (44 g/dL) which has higher lead concentration in blood compared to the homozygote ALAD 1-1 (38 g/dL) and homozygote ALAD 2-2 (56 $\mathrm{g} / \mathrm{dL}$ ) which is the highest lead concentration in blood. Further research conducted found three carrier individuals of genotype ALAD2 from 30 students in elementary school grade IV in Jakarta and six carrier individuals of genotype ALAD2 from $50 \mathrm{UNJ}$ students.

Detection of gene polymorphism begins with taking easily taken tissue samples such as peripheral blood, saliva, oral mucosa cells, and hair follicles [12] PCRARMS (Amplification Refractory Mutation System) is applied to discover polymorphism. PCR-ARMS enables simultaneous amplification of mutant allele and normal allele using two pairs of primer [14] Results of PCRARMS in this research would be used to differentiate the ALAD gene polymorphism genotype, namely the dominant homozygote (normal), mutant heterozygote, mutant recessive homozygote.
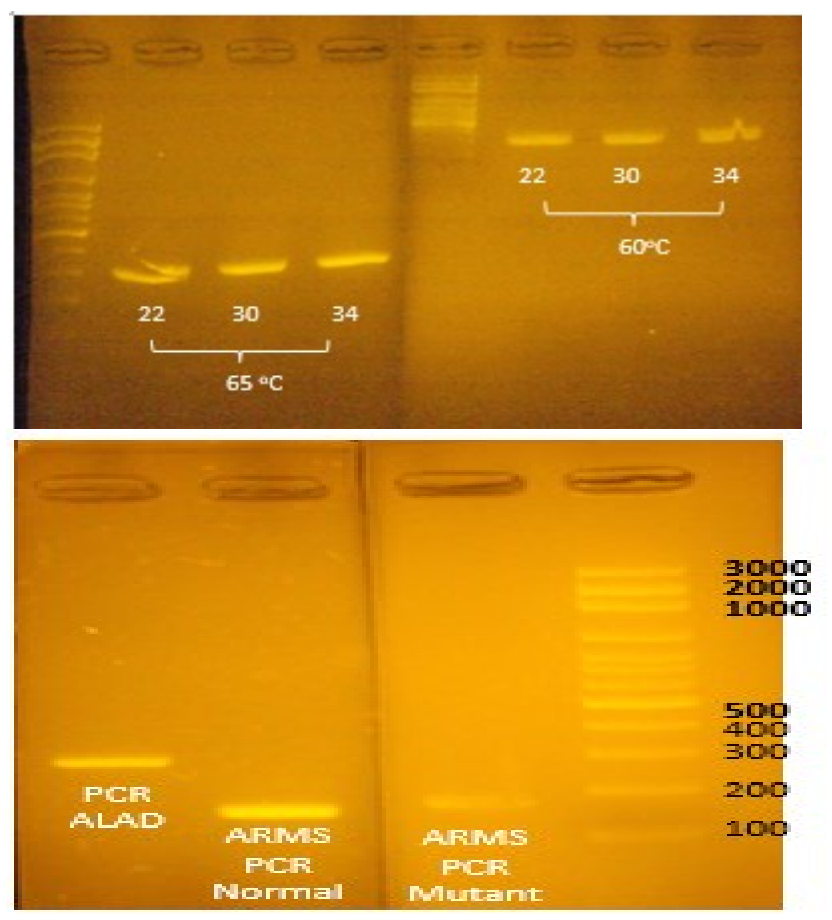

Fig. 3. Temperature optimization Electroforesis gen ALAD. 


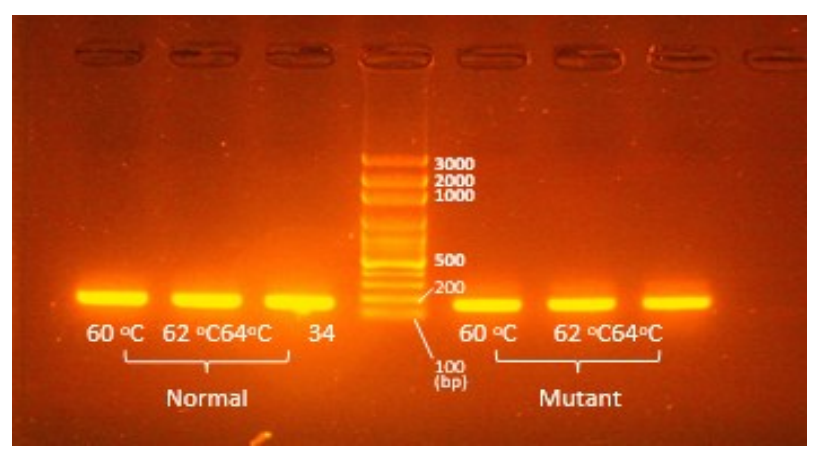

Fig. 4. Electrophoresis of PCR ARMS optimization temperature

The importance of ALAD gene polymorphism detection is the foundation of this research's aim to identify ALAD gene polymorphism and to discover the percentage of ALAD gene polymorphism. Moreover, blood hemoglobin level was examined to detect children with normal hemoglobin level, mild anemia, moderate anemia, or severe anemia. Afterwards, the relation between hemoglobin concentration and ALAD gene polymorphism would be examined. Further research regarding academic achievement and a study of behavioral problems in children can be categorized as internalization, externalization, and attention through the Pediatric Symptom Checklist 17 (PSC-17) questionnaire. From this data, the expected outcome is the solution to increase health and academic achievement of children.

Lead is rarely found in nature in its free state, instead it is found in the form of compounds with other molecules such as lead (II) bromide and lead (II) chloride [15] The additive which is commonly added into motor vehicle fuel consists of $62 \%$ tetraethyl lead [3] According to Environmen Project Agency in Gusnita [3] approximately $25 \%$ of the lead stays in the engine and the remaining $75 \%$ pollutes the air as exhaust fumes. Lead emission from vehicular exhaust fumes creates air pollution wherever the vehicle exists, with the following stages: $10 \%$ will pollute the location in a less than 100 meter radius; $5 \%$ will pollute the location in a 20 kilometer radius; and the remaining $35 \%$ will go into the atmosphere in quite a vast [4].

Lead compound in the body will bind the active group of the ALAD enzyme stopping the process of porphobilinogen creation [16] This would cause an accumulation of heme precursor, namely aminolevulinic acid (ALA). ALA would cause oxidative stress because it is mutagenic [10] Moreover, the exposure of lead also inhibits heme synthesis enzymes, inhibiting the production of heme. The decrease of heme would increase the ALAD synthesis activity which in turn increases the ALAD enzyme production. The increase of ALAD concentration can be discovered by measuring the excretion of lead in urine). [4] The exposure of lead to the body creates problems such as the increase of ALAD concentration in urine, shortening the life time of red blood cells, decreasing the quantity of red blood cells and reticulocytes resulting in the increasing risk of anemia [1].
Internalization problems originate from the pressure in the child's body, while externalization problems originate from environmental pressure, including conflicts with other people, attention focus, to the child's concentration. A research conducted by Puspitaningrum [1] showed positive results of the existence of ALAD gene mutation in 3 people from 30 students in elementary school grade IV in East Jakarta, which is an indication that the students were exposed to lead. A research towards college students showed that there were 6 carriers of ALAD gene mutation from $50 \mathrm{UNJ}$ students. In a further study, the existence of polymorphic ALAD gene has the implication that genetically, it has the potential of creating different susceptibility towards lead. The frequency of polymorphic is one from every nine people in a population ALAD gene is located in the long arm of chromosome 9.

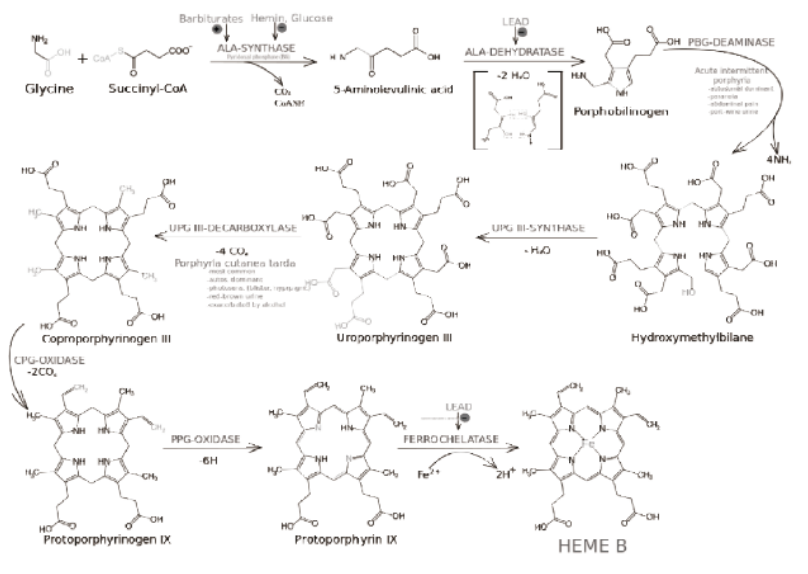

Fig. 5. Structure of gen ALAD [17].

In the position of 33.1. The ALAD gene, to be precise, is located from $113,386,312 \mathrm{bp}$ (base pair) to $113,401,338 \mathrm{bp}$ in chromosome 9 . ALAD gene gives the instruction to create delta aminolevulinic acid enzyme. Expressions of two alleles, namely ALAD-1 and ALAD2 create a polymorphic enzyme with three different isozymes, namely ALAD 1-1, ALAD 1-2, ALAD 2-2. The ALAD enzyme in humans shows a polymorphic enzyme. The cause of polymorphism in ALAD enzyme is the transversion from $\mathrm{G}$ to $\mathrm{C}$ in the nucleotide position 177 in the coding area which produce the amino acid substitution of lysine to asparagine [18].

ALAD enzyme (EC 4.2.1.24) is a tetramer formed from 8 identical subunits with one active site per dimer. This enzyme binds eight $\mathrm{Zn}$ atoms which function as catalyst and stabilization of the enzyme's tertiary structure. ALAD enzyme cannot bind the cofactor $\mathrm{Zn}$ because lead replaces the $\mathrm{Zn}$ ion. Lead acts as an inhibitor in the active group of the ALAD enzyme. ALAD enzyme would be inactive when there is a replacement of $\mathrm{Zn}$ atom to led atom. ALAD enzyme has an important role in the creation of red blood cells. Disturbance to ALAD enzyme would inhibit heme synthesis. This would shorten the lifetime of erythrocytes, disrupting the maturation of red blood cells and creating the risk of anemia [13] The inhibition of 
ALAD enzyme activity happens when the lead concentration is over $10 \mathrm{~g} / \mathrm{dL}$ in the blood.

\section{Conclusions}

The marine Task Force data of ALAD gene Test Results, within the of 100 Marines, the Alad gene mutation was not found.This means all the Marines in the sample are in optimal energy profile.

\section{References}

1. Puspitaningrum, Rini., Drajat, Gilang Ainan., Mujazanah., Istanti, Ristika Putri., Amelia, Ria., Graminie, Gladies Mercya. Seminar Nasional BKPSL-PPLH Universitas Sriwijaya. Polymorphism of ALAD Gene of Elementary School Students in East Jakarta- Indonesia., Palembang. (2016)

2. Puspitaningrum, Rini, Chris Adhiyanto, Annisa Firdausi, Nurmasari Sartono, Ria Amelia, Mella Ferania, Yukio Hattori, Yasuhiro Yamashiro, Riana Bagaskorowati, and Saparuddin Muktar.. Identification of The Levulinate Dehydratase (Alad) Gene Polymorphism and Whole Blood Hemoglobin in the Students of Elementary School in Kalideres, Jakarta, Indonesia. AJMBS. 19, 897-904 (2017)

3. Gusnita, Dessy. Pencemaran Logam Berat Timbal (Timbal) di Udara dan Upaya Penghapusan Bensin Bertimbal. Berita Dirgantara .13, 95-101 (2012)

4. Yamashiro, Yasuhiro., Hattori, Yukio., Ferania, Mella., Kentaro, Mori. UNJ Workshop of Molecular Genetics. (2014)

5. Widowati, Wahyu., Sastiono, Astiana., Jusuf R, Raymond. Efek Toksik Logam.Yogyakarta: Penerbit Andi. (2008)

6. Agustina, Titin. TEKNUBUGA Kontaminasi Logam Berat pada Makanan dan Dampaknya pada Kesehatan. 2. 53-65. (2010)

7. Saputra, Budi. Kajian Perubahan Penggunaan Lahan dari Hunian menjadi Industri dan Pergudangan (Studi Kasus: Di Wilayah Kelurahan Kamal dan Tegal Alur. Kecamatan Kalideres, Jakarta Barat. Thesis. Universitas Indonesia (2006)

8. Pramudyastuti, Triutami. Gambaran Hasil Pengukuran Konsentrasi Timbal di Udara dan Hubungannya dengan Kadar Hemoglobin dalam Darah Anak di Perumahan Kawasan Serpong. Skripsi. Universitas Indonesia (2010)

9. Izah, Nailul Saifi. Faktor-Faktor yang Berhubungan dengan Status Anemia Defisiensi Besi Anak Sekolah Kelas V dan VI MI Negeri 02 Cempaka Putih Ciputat Timur Tangerang Selatan. Skripsi. Universitas Islam Negeri Syarif Hidayatullah. (2011)

10. Azhari, Fitriani. Skripsi. Universitas Islam Negeri Syarif hidayatullah. Hubungan Kadar Timbal dalam Urin dan Karakteristik Individu dengan Kejadian
Anemia pada Pedagang Wanita di Terminal Kampung Rambutan Jakarta Timur. (2014)

11. Sunoko, Henna R. 2008. JMMI. Peran Gen Polimorfik $\delta$ Asam Amino Levulinat Dehidratase pada Intoksikasi Timbal. 43.1-10 (2008)

12. Patil, Arun J., Bhagwat, V R., Patil, J P., Dongre, N N., Ambekar, J G., Jailkhani, R., Das, K K. Int. J. Environ. Res. Public Health 3. Effect of Lead (Timbal) Exposure on the Activity of Superoxide Dismutase and Catalase in Battery Manufacturing Workers (BMW) of Western Maharashtra (India) with Reference to Heme biosynthesis. 4. 329-337 (2006)

13. Castiglioni, Evelyn Tiffany., Venkatraj, Vijayanagaram., Qian, Yongchang. . NeuroToxic. Genetic Polymorphisms and Mechanisms of Neurotoxicity: Overview. 26. 641-649 (2005)

14. Kelada, Samir N., Shelton, Erin., Kaufmann, Rachel B., Khoury, Muin J. AJE. $\delta$-Aminolevulinic Acid Dehydratase Genotype and Lead Toxicity: $A$ HuGE Review. 154. 1-13 (2001)

15. Chen, Qiaofang., Lu, Pin., Jones, Amy V., Cross, Nicholas C.P., Silver, Richard T., Wang, Lynn. J. of Mol Diag. Amplification Refractory Mutation System, a Highly Sensitive and Simple Polymerase Chain Reaction Assay, for the Detection of JAK2 V617F Mutation in Chronic Myeloproliferative Disorders. 9. 272-276 (2007)

16. Palar, H. Pencemaran dan Toksikologi Logam Berat. Jakarta: Penerbit Rineka Cipta (2008)

17. Puspitaningrum, Rini, Chris Adhiyanto, and Solihin. Genetika Molekuler danAplikasinya, FMIPApress. Jakarta. 38 (2018)

18. Rajaraman, P., Stewart, P A., Samet, J M., Schwartz, B S., Linet, M S., Zahm, S H., Rothman, N., Yeager, M., Fine, H A., Black, P M., Loeffler, J., Shapiro, W R., Selker, R G., Inskip, P D. Can. Epi. Bio. Prev. Lead, Genetic Susceptibility, and Risk of Adult Brain Tumors. 12. 2514-2520. (2006) 